Abstracta Iranica

Revue bibliographique pour le domaine irano-aryen

Volume 37-38-39 | 2018

Comptes rendus des publications de 2014-2016

\title{
James Howard-Johnston. "The Sasanian State: The Evidence of Coinage and Military Construction"
}

\section{Barbara Kaim}

\section{(2) OpenEdition}

1 Journals

\section{Édition électronique}

URL : http://journals.openedition.org/abstractairanica/46367

DOI : 10.4000/abstractairanica.46367

ISBN : 1961-960X

ISSN : 1961-960X

Éditeur :

CNRS (UMR 7528 Mondes iraniens et indiens), Éditions de l'IFRI

Référence électronique

Barbara Kaim, « James Howard-Johnston. "The Sasanian State: The Evidence of Coinage and Military Construction" », Abstracta Iranica [En ligne], Volume 37-38-39 | 2018, document 48, mis en ligne le 30 décembre 2018, consulté le 02 octobre 2020. URL : http://journals.openedition.org/abstractairanica/ 46367 ; DOI : https://doi.org/10.4000/abstractairanica.46367

Ce document a été généré automatiquement le 2 octobre 2020.

Tous droits réservés 


\title{
James Howard-Johnston. "The Sasanian State: The Evidence of Coinage and Military Construction"
}

\author{
Barbara Kaim
}

\section{RÉFÉRENCE}

James Howard-Johnston. "The Sasanian State: The Evidence of Coinage and Military Construction" in Richard Payne, Mehrnoush Soroush (eds.). The Archaeology of Sasanian Politics. Berlin: De Gruyter, 2014, p. 144-181 (Journal of Ancient History - special issue, 2.2)

1 En utilisant les données archéologiques et numismatiques ainsi que les textes historiques, l'A. dresse un tableau de l'empire sassanide en tant qu'entité politique forte et centralisé, capable de maintenir le pouvoir sur tous les coins de cet immense et hétérogène territoire. Sur le territoire contrôlé par les Sassanides circulaient les pièces frappées dans différentes villes de l'empire mais au sein d'un seul système monétaire étroitement contrôlé.

\section{AUTEURS}

\section{BARBARA KAIM}

Université de Varsovie 